\title{
Virgibacillus dokdonensis sp. nov., isolated from a Korean island, Dokdo, located at the edge of the East Sea in Korea
}

\author{
Jung-Hoon Yoon, So-Jung Kang, Soo-Young Lee, Mi-Hwa Lee \\ and Tae-Kwang Oh \\ Korea Research Institute of Bioscience and Biotechnology (KRIBB), PO Box 115, Yusong, \\ Taejon, South Korea
}

Correspondence

Tae-Kwang Oh

otk@kribb.re.kr

Jung-Hoon Yoon

jhyoon@kribb.re.kr
A Gram-variable, motile, endospore-forming, slightly halophilic bacterial strain, DSW-10 ${ }^{\top}$, was isolated from Dokdo, an island located at the edge of the East Sea, Korea, and was characterized taxonomically by using a polyphasic approach. This isolate grew optimally at $37{ }^{\circ} \mathrm{C}$ and in the presence of $4-5 \% \mathrm{NaCl}$. Strain DSW $-10^{\top}$ had cell-wall peptidoglycan based on

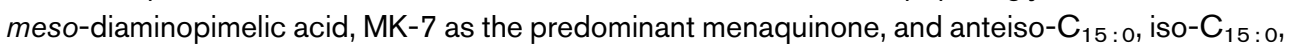
anteiso- $\mathrm{C}_{17: 0}$ and iso- $\mathrm{C}_{16: 0}$ as major fatty acids. Major polar lipids were diphosphatidylglycerol, phosphatidylglycerol, phosphatidylethanolamine and unidentified phospholipids. The DNA $\mathrm{G}+\mathrm{C}$ content was $36 \cdot 7$ mol\%. Phylogenetic analyses based on $16 \mathrm{~S}$ rRNA gene sequences showed that strain DSW $-10^{\top}$ is phylogenetically affiliated to the genus Virgibacillus, and exhibited sequence similarity of $95 \cdot 3-98 \cdot 7 \%$ to the type strains of Virgibacillus species. DNA-DNA relatedness levels between strain DSW $-10^{\top}$ and the type strains of some phylogenetically related Virgibacillus species were in the range $8 \cdot 4-17 \cdot 5 \%$. On the basis of phenotypic properties and phylogenetic and genetic distinctiveness, strain DSW $-10^{\top}\left(=\right.$ KCTC $\left.3933^{\top}=\mathrm{DSM} 16826^{\top}\right)$ was classified as the type strain of a novel Virgibacillus species, for which the name Virgibacillus dokdonensis sp. nov. is proposed.
The genus Virgibacillus was first proposed by Heyndrickx et al. (1998) with the transfer of Bacillus pantothenticus to Virgibacillus pantothenticus. Subsequently, four further species, Virgibacillus proomii (Heyndrickx et al., 1999) and Virgibacillus carmonensis, Virgibacillus necropolis and Virgibacillus picturae (Heyrman et al., 2003), were described. Two Salibacillus species (Wainø et al., 1999; Arahal et al., 2000) have been reclassified in the genus as Virgibacillus marismortui and Virgibacillus salexigens (Heyrman et al., 2003). Recently, Bacillus halodenitrificans was transferred to the genus as Virgibacillus halodenitrificans (Yoon et al., 2004). The genus Virgibacillus currently comprises eight recognized species. Here we report on the taxonomic characterization of a slightly halophilic Virgibacillus-like bacterial strain, DSW $-10^{\mathrm{T}}$, which was isolated from sea water at Dokdo, an island in the East Sea, Korea.

Sea water collected at Dokdo provided the source for

Published online ahead of print on 22 April 2005 as DOI 10.1099/ ijs.0.63613-0.

Abbreviation: TEM, transmission electron microscopy.

The GenBank/EMBL/DDBJ accession number for the 16S rRNA gene sequence of strain DSW- $10^{\top}$ is AY822043. isolation of the bacterial strains. A single isolate, DSW $-10^{\mathrm{T}}$, was obtained by the standard dilution plating technique on marine agar 2216 (MA; Difco) at $30^{\circ} \mathrm{C}$. V. pantothenticus DSM $26^{\mathrm{T}}$, V. proomii DSM $13055^{\mathrm{T}}$ and $V$. marismortui DSM $12325^{\mathrm{T}}$ were obtained from the Deutsche Sammlung von Mikroorganismen und Zellkulturen (DSMZ), Braunschweig, Germany, and cultivated according to recommended procedures of the DSMZ. Cell morphology was examined by light microscopy (Nikon E600) and transmission electron microscopy (TEM). For the latter, cells were negatively stained with $1 \%(\mathrm{w} / \mathrm{v})$ phosphotungstic acid and, after air-drying, the grids were examined by using a model CM-20 transmission electron microscope (Philips). Presence of flagella was examined by TEM using cells from exponentially growing cultures. The Gram-reaction was determined using the bioMérieux Gram Stain kit according to the manufacturer's instructions. Growth under anaerobic conditions was determined after incubation in an anaerobic chamber on MA and MA supplemented with nitrate, both of which had been prepared anaerobically. The $\mathrm{pH}$ range for growth was determined in marine broth 2216 (MB; Difco) supplemented with $3 \%$ $(\mathrm{w} / \mathrm{v}) \mathrm{NaCl}$ that was adjusted to various $\mathrm{pH}$ values (initial $\mathrm{pH} 4 \cdot 0-12 \cdot 0$ at intervals of $0 \cdot 5 \mathrm{pH}$ units). The $\mathrm{pH}$ (below 
10.5) was adjusted prior to sterilization to various levels by the addition of $\mathrm{HCl}$ or $\mathrm{Na}_{2} \mathrm{CO}_{3}$. Growth at various $\mathrm{NaCl}$ concentrations was investigated in $\mathrm{MB}$ or trypticase soy broth (TSB; Difco). Growth in the absence of $\mathrm{NaCl}$ was investigated in TSB lacking $\mathrm{NaCl}$. Growth at various temperatures $\left(4-55^{\circ} \mathrm{C}\right)$ was measured on MA supplemented with $3 \%(\mathrm{w} / \mathrm{v}) \mathrm{NaCl}$. Oxidase and catalase activities and hydrolysis of casein, starch, urea and Tweens 20, 40, 60 and 80 were determined as described by Cowan \& Steel (1965). Hydrolysis of aesculin and gelatin and nitrate reduction were determined as described by Lanyi (1987) with a modification that artificial sea water was used for preparation of media. The artificial sea water contained (per litre distilled water) $23.6 \mathrm{~g} \mathrm{NaCl}, 0.64 \mathrm{~g} \mathrm{KCl}, 4.53 \mathrm{~g} \mathrm{MgCl}_{2} .6 \mathrm{H}_{2} \mathrm{O}, 5.94 \mathrm{~g}$ $\mathrm{MgSO}_{4} .7 \mathrm{H}_{2} \mathrm{O}$ and $1.3 \mathrm{~g} \mathrm{CaCl}_{2} \cdot 2 \mathrm{H}_{2} \mathrm{O}$ (Bruns et al., 2001). $\mathrm{H}_{2} \mathrm{~S}$ production was tested as described by Bruns et al. (2001). Hydrolysis of hypoxanthine, tyrosine and xanthine was performed on MA supplemented with $3 \% \mathrm{NaCl}$ using the substrate concentrations given by Cowan \& Steel (1965). Acid production from carbohydrates was determined as described by Leifson (1963), and utilization of various substrates as sole carbon and energy sources was tested according to the method of Baumann \& Baumann (1981) using supplementation with $2 \%(\mathrm{v} / \mathrm{v})$ Hutner's mineral base (Cohen-Bazire et al., 1957), $1 \%$ (v/v) vitamin solution (Staley, 1968) and $0.01 \%(\mathrm{w} / \mathrm{v})$ yeast extract. Enzyme activity and other physiological properties were determined using the API ZYM and API 20E systems (bioMérieux) with a modification that suspension media supplemented with $5 \%(\mathrm{w} / \mathrm{v}) \mathrm{NaCl}$ were used.

Cell mass for analyses of the cell wall, menaquinones and polar lipids and for DNA extraction was produced in $\mathrm{MB}$ supplemented with $3 \% \mathrm{NaCl}$ at $37^{\circ} \mathrm{C}$. The isomer type of diaminopimelic acid in the peptidoglycan was determined by the method described by Komagata \& Suzuki (1987). Menaquinones were analysed as described by Komagata \& Suzuki (1987) using reversed-phase HPLC. Polar lipids were extracted using the procedures described by Minnikin et al. (1984) and were identified by two-dimensional TLC followed by spraying with appropriate detection reagents (Komagata \& Suzuki, 1987). For fatty acid methyl ester analysis, cell mass of strain DSW $-10^{\mathrm{T}}$ was harvested from agar plates after cultivation for 2 days at $37^{\circ} \mathrm{C}$ on $\mathrm{MA}$ supplemented with $3 \% \mathrm{NaCl}$. The fatty acid methyl esters were extracted and prepared according to the standard protocol of the MIDI/Hewlett Packard Microbial Identification System (Sasser, 1990). Chromosomal DNA was isolated and purified according to the method described by Yoon et al. (1996), with the exception that RNase T1 was used in combination with RNase A. The DNA G + C content was determined by the method of Tamaoka \& Komagata (1984) with a modification that DNA was hydrolysed and the resultant nucleotides were analysed by reversed-phase HPLC. The 16S rRNA gene was amplified by PCR using two universal primers as described by Yoon et al. (1998). Sequencing of the $16 \mathrm{~S}$ rRNA gene and phylogenetic analysis were performed as described by Yoon et al. (2003). DNADNA hybridization was performed fluorometrically by the method of Ezaki et al. (1989) using photobiotin-labelled DNA probes and microdilution wells. Hybridization was performed with five replications for each sample. The highest and lowest values obtained for each sample were excluded and the means of the remaining three values were quoted as DNA-DNA relatedness values.

The $16 \mathrm{~S}$ rRNA gene sequence of strain DSW $-10^{\mathrm{T}}$ determined in this study comprised $1520 \mathrm{nt}$, representing approximately $96 \%$ of the Escherichia coli $16 \mathrm{~S}$ rRNA gene sequence. Comparative $16 \mathrm{~S}$ rRNA gene sequence analyses showed that strain DSW $-10^{\mathrm{T}}$ is most closely related to Virgibacillus species (Fig. 1). In the phylogenetic tree based on the neighbour-joining algorithm, strain DSW$10^{\mathrm{T}}$ joined $V$. pantothenticus at a bootstrap confidence level of $99 \cdot 3 \%$ (Fig. 1). Although there were differences in topologies between the phylogenetic tree based on the neighbour-joining algorithm and those based on the maximum-likelihood and maximum-parsimony algorithms, the relationships among strain DSW $-10^{\mathrm{T}}$ and some Virgibacillus species were also recovered in the trees based on the latter two algorithms (Fig. 1). Strain DSW $-10^{\mathrm{T}}$ exhibited $16 \mathrm{~S}$ rRNA gene sequence similarity values of $98.7 \%$ to $\mathrm{V}$. pantothenticus IAM $11061^{\mathrm{T}}$ and $95 \cdot 3-97 \cdot 0 \%$ to the type strains of the other Virgibacillus species (Fig. 1). Sequence similarities to all other species included in the phylogenetic analysis were lower than $94 \cdot 3 \%$ (Fig. 1). DNA-DNA

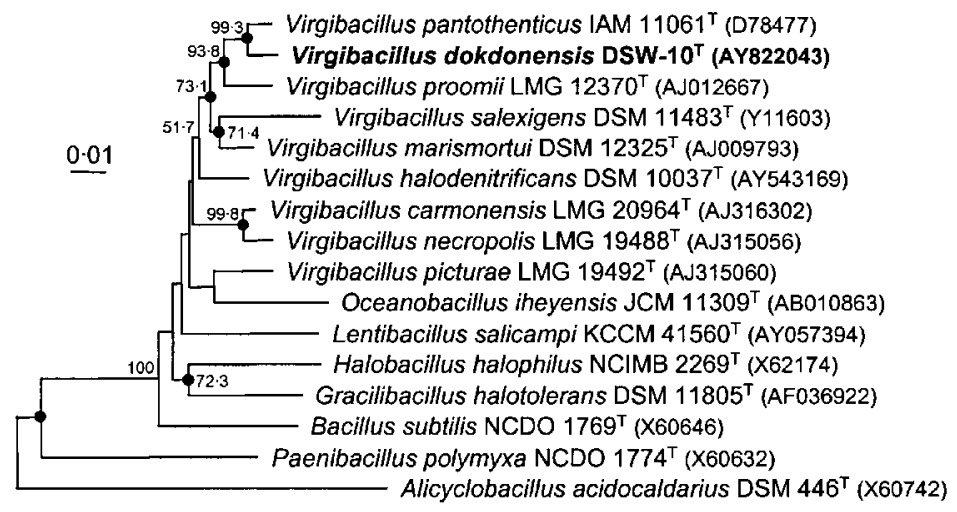

Fig. 1. Neighbour-joining tree based on $16 \mathrm{~S}$ rRNA gene sequence data showing the phylogenetic positions of strain $\mathrm{DSW}-10^{\top}$, Virgibacillus species and other related taxa. Bootstrap values of $50 \%$ or greater (1000 replications) are shown as percentages at each node. Bar, 0.01 substitutions per nucleotide position. Dots indicate that the corresponding nodes are also recovered in trees generated with the maximum-likelihood and maximum-parsimony algorithms. 
hybridization was performed to determine the genetic relatedness between strain DSW- $10^{\mathrm{T}}$ and the type strains of three Virgibacillus species that showed 16S rRNA gene sequence similarity values of $>97 \cdot 0 \%$ to strain DSW $-10^{\mathrm{T}}$. Strain DSW $-10^{\mathrm{T}}$ exhibited DNA-DNA relatedness levels of $17 \cdot 5,8 \cdot 4$ and $9 \cdot 2 \%$ to $V$. pantothenticus DSM $26^{\mathrm{T}}, \mathrm{V}$. proomii DSM $13055^{\mathrm{T}}$ and V. marismortui DSM $12325^{\mathrm{T}}$, respectively.
Morphological, cultural, physiological and biochemical characteristics of strain DSW- $10^{\mathrm{T}}$ are shown in Table 1 or are given in the species description below. Strain DSW-10 contained meso-diaminopimelic acid as the diagnostic diamino acid in the cell-wall peptidoglycan. The predominant isoprenoid quinone found in strain DSW- $10^{\mathrm{T}}$ was unsaturated menaquinone with seven isoprene units (MK-7), and a minor amount of MK-6 was also detected. Major

Table 1. Differential phenotypic characteristics of Virgibacillus dokdonensis sp. nov. and other Virgibacillus species

Species: 1, V. dokdonensis sp. nov.; 2, V. pantothenticus (data from Heyndrickx et al., 1999; Heyrman et al., 2003); 3, V. proomii (Heyndrickx et al., 1999; Heyrman et al., 2003); 4, V. salexigens (Wainø et al., 1999; Heyrman et al., 2003); 5, V. marismortui (Arahal et al., 1999, 2000; Heyrman et al., 2003); 6, V. carmonensis (Heyrman et al., 2003); 7, V. necropolis (Heyrman et al., 2003); 8, V. picturae (Heyrman et al., 2003); 9, V. halodenitrificans (Yoon et al., 2004). +, Positive; -, negative; W, weakly positive; ND, not determined; V, variable; E, ellipsoidal; s, spherical; C, central; ST, subterminal; T, terminal; PG, phosphatidylglycerol; DPG, diphosphatidylglycerol; PE, phosphatidylethanolamine; PLs, unidentified phospholipids; APL, unknown aminophospholipid; tr, trace. Data in parentheses are for the type strain. Cells of all species are rod-shaped, motile, positive for catalase and negative for growth on D-arabinose and D-xylose.

\begin{tabular}{|c|c|c|c|c|c|c|c|c|c|}
\hline Character & 1 & 2 & 3 & 4 & 5 & 6 & 7 & 8 & 9 \\
\hline Spore position & $\mathrm{T}$ or $\mathrm{ST}$ & $\mathrm{T}$ or $\mathrm{ST}$ & $\mathrm{T}$ or $\mathrm{ST}$ & C, ST or $\mathrm{T}$ & $\mathrm{T}$ or $\mathrm{ST}$ & ST & C, ST or $\mathrm{T}$ & $\mathrm{T}$ & $\mathrm{T}$ or $\mathrm{ST}$ \\
\hline Pigmentation & - & - & - & - & - & Pink & - & - & - \\
\hline Anaerobic growth & + & + & + & - & - & - & - & - & + \\
\hline \multicolumn{10}{|l|}{ Growth in the presence of: } \\
\hline $25 \% \mathrm{NaCl}$ & - & - & - & $\mathrm{W}^{*}$ & - & - & - & - & $\mathrm{V}(+)$ \\
\hline Temperature range $\left({ }^{\circ} \mathrm{C}\right)$ & $15-50$ & $15-50$ & $15-50$ & $15-45$ & $15-50$ & $10-40$ & $10-40$ & $5-40$ & $10-45$ \\
\hline Nitrate reduction & - & $\mathrm{V}$ & - & - & + & + & + & + & + \\
\hline $\mathrm{H}_{2} \mathrm{~S}$ production & - & $\mathrm{V}$ & - & + & + & - & - & - & - \\
\hline \multicolumn{10}{|l|}{ Hydrolysis of: } \\
\hline D-Glucose & + & $\mathrm{W}$ & $\mathrm{W}$ & $\mathrm{W}$ & - & - & + & $\mathrm{V}$ & + \\
\hline D-Fructose & + & - & - & - & - & - & - & - & $\mathrm{V}(+)$ \\
\hline Sucrose & + & - & + & + & + & + & + & $\mathrm{V}$ & + \\
\hline \multicolumn{10}{|l|}{ Acid production from: $\dagger$} \\
\hline D-Galactose & + & - & + & $\mathrm{W}$ & - & - & - & $\mathrm{W}$ & + \\
\hline D-Glucose & + & - & + & $\mathrm{w}$ & + & - & $\mathrm{w}$ & $\mathrm{w}$ & + \\
\hline D-Fructose & + & - & + & $\mathrm{w}$ & + & - & $\mathrm{w}$ & $\mathrm{w}$ & + \\
\hline D-Mannose & + & - & + & $\mathrm{W}$ & + & - & $\mathrm{W}$ & $\mathrm{W}$ & + \\
\hline D-Melibiose & - & - & - & - & - & - & - & $\mathrm{W}$ & - \\
\hline L-Rhamnose & - & + & $\mathrm{V}$ & - & - & - & - & - & - \\
\hline D-Trehalose & - & + & + & - & - & - & $\mathrm{w}$ & $\mathrm{V}$ & + \\
\hline
\end{tabular}

${ }^{\star}$ Data from Heyrman et al. (2003); a different result was obtained by Wainø et al. (1999).

$\dagger$ Data for $V$. dokdonensis were obtained using the methods of Leifson (1963); data for the other Virgibacillus species were obtained using the API 50CHB system (bioMérieux) by Heyrman et al. (2003). 
components of the fatty acids $(>1 \%)$ detected in strain DSW $-10^{\mathrm{T}}$ were branched fatty acids anteiso- $\mathrm{C}_{15: 0}(34 \cdot 4 \%)$, iso- $\mathrm{C}_{15: 0}(19 \cdot 4 \%)$, anteiso- $\mathrm{C}_{17: 0}(15 \cdot 4 \%)$, iso- $\mathrm{C}_{16: 0}$ $(12 \cdot 3 \%)$, iso- $\mathrm{C}_{17: 0}(7 \cdot 2 \%)$, iso- $\mathrm{C}_{14: 0}(4 \cdot 7 \%)$ and iso$\mathrm{C}_{13: 0}(1 \cdot 1 \%)$ and straight-chain fatty acid $\mathrm{C}_{16: 0}(2 \cdot 4 \%)$. This fatty acid profile was similar to those of Virgibacillus species, although there were differences in the proportions of some fatty acids that might have been caused by different cultivation conditions (Heyndrickx et al., 1999; Wainø et al., 1999; Heyrman et al., 2003). Major polar lipids detected in strain DSW $-10^{\mathrm{T}}$ were diphosphatidylglycerol, phosphatidylglycerol, phosphatidylethanolamine and unidentified phospholipids. An unknown aminophospholipid that was ninhydrin-positive was not detected. The DNA G+C content of strain DSW $-10^{\mathrm{T}}$ was $36 \cdot 7 \mathrm{~mol} \%$. The results obtained from chemotaxonomic analyses, showing the properties that are shared by Virgibacillus species, were in agreement with the result of phylogenetic classification based on 16S rRNA gene sequence analysis.

There are some differences in the phenotypic characteristics of strain DSW $-10^{\mathrm{T}}$ and recognized Virgibacillus species (Table 1). In particular, strain DSW $-10^{\mathrm{T}}$ is clearly distinguished from $V$. pantothenticus, its nearest phylogenetic neighbour, by differences in acid production from some substrates (Table 1). The phylogenetic distinctiveness and DNA-DNA relatedness data are sufficient to categorize strain DSW $-10^{\mathrm{T}}$ as representing a species that is distinct from recognized Virgibacillus species (Wayne et al., 1987; Stackebrandt \& Goebel, 1994). Therefore, on the basis of the data presented, strain DSW-10 ${ }^{\mathrm{T}}$ should be classified in the genus Virgibacillus as a member of a novel species, for which the name Virgibacillus dokdonensis sp. nov. is proposed.

\section{Description of Virgibacillus dokdonensis sp. nov.}

Virgibacillus dokdonensis (dok.do.nen'sis. N.L. masc. adj. dokdonensis of Dokdo, a Korean island located at the edge of the East Sea in Korea from where the type strain was isolated).

Cells are rod-shaped, $0 \cdot 6-0 \cdot 8 \times 2 \cdot 5-5 \cdot 0 \mu \mathrm{m}$, Gram-variable and motile by means of peritrichous flagella. Terminal or subterminal ellipsoidal or spherical endospores are observed in swollen sporangia. Colonies are irregular, flat, translucent, milky white in colour and $3-5 \mathrm{~mm}$ in diameter after 2 days of incubation at $37^{\circ} \mathrm{C}$ on $\mathrm{MA}$ supplemented with $3 \%(\mathrm{w} / \mathrm{v}) \mathrm{NaCl}$. Optimal growth temperature is $37^{\circ} \mathrm{C}$; growth occurs at 15 and $50^{\circ} \mathrm{C}$, but not at 10 or $55^{\circ} \mathrm{C}$. Optimal $\mathrm{pH}$ for growth is $7 \cdot 0-8 \cdot 0$; growth occurs at $\mathrm{pH} 5 \cdot 5$, but not at $\mathrm{pH} 5 \cdot 0$. Optimal growth occurs in the presence of $4-5 \%(\mathrm{w} / \mathrm{v}) \mathrm{NaCl}$; growth occurs without $\mathrm{NaCl}$ and in the presence of $23 \%(\mathrm{w} / \mathrm{v}) \mathrm{NaCl}$, but not in the presence of $>24 \%(\mathrm{w} / \mathrm{v}) \mathrm{NaCl}$. Growth occurs under anaerobic conditions on MA and MA supplemented with nitrate. Oxidase-positive. Urease-negative. Starch and Tweens 20, 40, 60 and 80 are hydrolysed. Hypoxanthine, xanthines and tyrosine are not hydrolysed. Voges-Proskauer reaction is negative. Indole is not produced. Arginine dihydrolase, lysine decarboxylase and ornithine decarboxylase are absent. When assayed with the API ZYM system, alkaline phosphatase, esterase (C4), esterase lipase (C8), $\alpha$-chymotrypsin, naphthol-AS-BI-phosphohydrolase and $\alpha$-glucosidase are present, but lipase (C14), leucine arylamidase, valine arylamidase, cystine arylamidase, trypsin, acid phosphatase, $\alpha$-galactosidase, $\beta$-galactosidase, $\beta$-glucuronidase, $\beta$ glucosidase, $N$-acetyl- $\beta$-glucosaminidase, $\alpha$-mannosidase and $\alpha$-fucosidase are absent. Acid is produced from Dcellobiose, lactose, maltose, D-ribose, sucrose, myo-inositol and D-sorbitol. Acid is not produced from L-arabinose, Dmelezitose, D-raffinose or D-xylose. The following substrates are utilized: D-cellobiose, D-mannose, maltose, acetate, citrate, pyruvate and salicin. D-Galactose, Dtrehalose, benzoate, succinate, L-malate, formate and Lglutamate are not utilized. The cell-wall peptidoglycan contains meso-diaminopimelic acid. The predominant menaquinone is MK-7. The major polar lipids are diphosphatidylglycerol, phosphatidylglycerol, phosphatidylethanolamine and unidentified phospholipids. The major fatty acids are anteiso- $\mathrm{C}_{15: 0}(34 \cdot 4 \%)$, iso- $\mathrm{C}_{15: 0}(19 \cdot 4 \%)$, anteiso- $\mathrm{C}_{17: 0}(15 \cdot 4 \%)$ and iso- $\mathrm{C}_{16: 0}(12 \cdot 3 \%)$. The DNA $\mathrm{G}+\mathrm{C}$ content is $36 \cdot 7 \mathrm{~mol} \%$.

The type strain, DSW $-10^{\mathrm{T}}\left(=\mathrm{KCTC} 3933^{\mathrm{T}}=\mathrm{DSM} 16826^{\mathrm{T}}\right)$, was isolated from Dokdo, an island located at the edge of the East Sea, Korea.

\section{Acknowledgements}

This work was supported by the 21C Frontier program of Microbial Genomics and Applications (grant MG02-0401-001-1-0-0) from the Ministry of Science and Technology (MOST) of the Republic of Korea. We are grateful to Cultural Heritage Administration and Gyeongsangbuk-do Administration of the Republic of Korea for permission to enter Dokdo.

\section{References}

Arahal, D. R., Márquez, M. C., Volcani, B. E., Schleifer, K. H. \& Ventosa, A. (1999). Bacillus marismortui sp. nov., a new moderately halophilic species from the Dead Sea. Int J Syst Bacteriol 49, 521-530.

Arahal, D. R., Márquez, M. C., Volcani, B. E., Schleifer, K. H. \& Ventosa, A. (2000). Reclassification of Bacillus marismortui as Salibacillus marismortui comb. nov. Int J Syst Evol Microbiol 50, 1501-1503.

Baumann, P. \& Baumann, L. (1981). The marine Gram-negative eubacteria: genera Photobacterium, Beneckea, Alteromonas, Pseudomonas, and Alcaligenes. In The Prokaryotes, pp. 1302-1331. Edited by M. P. Starr, H. Stolp, H. G. Trüper, A. Balows \& H. G. Schlegel. Berlin: Springer.

Bruns, A., Rohde, M. \& Berthe-Corti, L. (2001). Muricauda ruestringensis gen. nov., sp. nov., a facultatively anaerobic, appendaged bacterium from German North Sea intertidal sediment. Int J Syst Evol Microbiol 51, 1997-2006.

Cohen-Bazire, G., Sistrom, W. R. \& Stanier, R. Y. (1957). Kinetic studies of pigment synthesis by nonsulfur purple bacteria. $J$ Cell Comp Physiol 49, 25-68. 
Cowan, S. T. \& Steel, K. J. (1965). Manual for the Identification of Medical Bacteria. London: Cambridge University Press.

Ezaki, T., Hashimoto, Y. \& Yabuuchi, E. (1989). Fluorometric deoxyribonucleic acid-deoxyribonucleic acid hybridization in microdilution wells as an alternative to membrane filter hybridization in which radioisotopes are used to determine genetic relatedness among bacterial strains. Int J Syst Bacteriol 39, 224-229.

Heyndrickx, M., Lebbe, L., Kersters, K., De Vos, P., Forsyth, G. \& Logan, N. A. (1998). Virgibacillus: a new genus to accommodate Bacillus pantothenticus (Proom and Knight 1950). Emended description of Virgibacillus pantothenticus. Int J Syst Bacteriol 48, 99-106.

Heyndrickx, M., Lebbe, L., Kersters, K., Hoste, B., De Wachter, R., De Vos, P., Forsyth, G. \& Logan, N. A. (1999). Proposal of Virgibacillus proomii sp. nov. and emended description of Virgibacillus pantothenticus (Proom and Knight 1950) Heyndrickx et al. 1998. Int J Syst Bacteriol 49, 1083-1090.

Heyrman, J., Logan, N. A., Busse, H.-J., Balcaen, A., Lebbe, L., Rodriguez-Diaz, M., Swings, J. \& De Vos, P. (2003). Virgibacillus carmonensis sp. nov., Virgibacillus necropolis sp. nov. and Virgibacillus picturae sp. nov., three novel species isolated from deteriorated mural paintings, transfer of the species of the genus Salibacillus to Virgibacillus, as Virgibacillus marismortui comb. nov. and Virgibacillus salexigens comb. nov., and emended description of the genus Virgibacillus. Int J Syst Evol Microbiol 53, 501-511.

Komagata, K. \& Suzuki, K. (1987). Lipids and cell-wall analysis in bacterial systematics. Methods Microbiol 19, 161-203.

Lanyi, B. (1987). Classical and rapid identification methods for medically important bacteria. Methods Microbiol 19, 1-67.

Leifson, E. (1963). Determination of carbohydrate metabolism of marine bacteria. J Bacteriol 85, 1183-1184.

Minnikin, D. E., O’Donnell, A. G., Goodfellow, M., Alderson, G., Athalye, M., Schaal, A. \& Parlett, J. H. (1984). An integrated procedure for the extraction of bacterial isoprenoid quinones and polar lipids. J Microbiol Methods 2, 233-241.
Sasser, M. (1990). Identification of bacteria by gas chromatography of cellular fatty acids. Newark, DE: MIDI Inc.

Stackebrandt, E. \& Goebel, B. M. (1994). Taxonomic note: a place for DNA-DNA reassociation and 16S rRNA sequence analysis in the present species definition in bacteriology. Int J Syst Bacteriol 44, 846-849.

Staley, J. T. (1968). Prosthecomicrobium and Ancalomicrobium: new prosthecate freshwater bacteria. J Bacteriol 95, 1921-1942.

Tamaoka, J. \& Komagata, K. (1984). Determination of DNA base composition by reverse-phase high-performance liquid chromatography. FEMS Microbiol Lett 25, 125-128.

Wainø, M., Tindall, B. J., Schumann, P. \& Ingvorsen, K. (1999). Gracilibacillus gen. nov., with description of Gracilibacillus halotolerans gen. nov., sp. nov.; transfer of Bacillus dipsosauri to Gracilibacillus dipsosauri comb. nov., and Bacillus salexigens to the genus Salibacillus gen. nov., as Salibacillus salexigens comb. nov. Int J Syst Bacteriol 49, 821-831.

Wayne, L. G., Brenner, D. J., Colwell, R. R. \& 9 other authors (1987). Report of the ad hoc committee on reconciliation of approaches to bacterial systematics. Int J Syst Bacteriol 37, 463-464.

Yoon, J.-H., Kim, H., Kim, S.-B., Kim, H.-J., Kim, W. Y., Lee, S. T., Goodfellow, M. \& Park, Y.-H. (1996). Identification of Saccharomonospora strains by the use of genomic DNA fragments and rRNA gene probes. Int J Syst Bacteriol 46, 502-505.

Yoon, J.-H., Lee, S. T. \& Park, Y.-H. (1998). Inter- and intraspecific phylogenetic analysis of the genus Nocardioides and related taxa based on 16S rDNA sequences. Int J Syst Bacteriol 48, 187-194.

Yoon, J.-H., Kim, I.-G., Kang, K. H., Oh, T.-K. \& Park, Y.-H. (2003). Bacillus marisflavi sp. nov. and Bacillus aquimaris sp. nov., isolated from sea water of a tidal flat of the Yellow Sea in Korea. Int J Syst Evol Microbiol 53, 1297-1303.

Yoon, J.-H., Oh, T.-K. \& Park, Y.-H. (2004). Transfer of Bacillus halodenitrificans Denariaz et al. 1989 to the genus Virgibacillus as Virgibacillus halodenitrificans comb. nov. Int J Syst Evol Microbiol 54, 2163-2167. 